\title{
CFD MODELING OF SYNGAS COMBUSTION AND EMISSIONS FOR MARINE GAS TURBINE APPLICATIONS
}

\author{
Nader R. Ammar \\ Ahmed I. Farag \\ Department of Naval Architecture \& Marine Engineering, \\ Alexandria University, Egypt
}

\begin{abstract}
Strong restrictions on emissions from marine power plants will probably be adopted in the near future. One of the measures which can be considered to reduce exhaust gases emissions is the use of alternative fuels. Synthesis gases are considered competitive renewable gaseous fuels which can be used in marine gas turbines for both propulsion and electric power generation on ships. The paper analyses combustion and emission characteristics of syngas fuel in marine gas turbines. Syngas fuel is burned in a gas turbine can combustor. The gas turbine can combustor with swirl is designed to burn the fuel efficiently and reduce the emissions. The analysis is performed numerically using the computational fluid dynamics code ANSYS FLUENT. Different operating conditions are considered within the numerical runs. The obtained numerical results are compared with experimental data and satisfactory agreement is obtained. The effect of syngas fuel composition and the swirl number values on temperature contours, and exhaust gas species concentrations are presented in this paper. The results show an increase of peak flame temperature for the syngas compared to natural gas fuel combustion at the same operating conditions while the NO emission becomes lower. In addition, lower CO2 emissions and increased CO emissions at the combustor exit are obtained for the syngas, compared to the natural gas fuel.
\end{abstract}

Keywords: CFD, Syngas fuel, Combustion characteristics, Exhaust gas emissions.

\section{INTRODUCTION}

Emissions from the marine transport sector contribute significantly to air pollution globally [1,2, and 3]. Around $15 \%$ of global nitrogen oxides $\left(\mathrm{NO}_{\mathrm{x}}\right), 2.7 \%$ of global $\mathrm{CO}_{2}$ emissions, and $5-8 \%$ of global sulfur oxides $\left(\mathrm{SO}_{\mathrm{x}}\right)$ emissions are produced by oceangoing ships $[3,4,5$, and $6,7,8]$. As a result of maritime transport emissions, the International Maritime Organization (IMO) has implemented mandatory regulations to reduce these exhaust gas emissions. On the one hand, $\mathrm{NO}_{\mathrm{x}}$ emissions fall under IMO Regulation 13 and a number of methods can be used to meet the emission limits [9]. On the other hand, IMO Regulation 14 dictates the emission limits for $\mathrm{SO}_{\mathrm{x}}$ and carbon particles from ships. In addition, IMO marine environmental protection committee requires increasing the energy efficiency of new ships to reduce $\mathrm{CO}_{2}$ emissions from ships [10]. These environmental legislations on emissions from ships can be met by either refining the fuel with the aid of one or more systems of exhaust gas cleaning to reduce sulfur content, or by using an alternative clean fuel $[10,11]$. Synthesis gas fuel is one of challenging renewable fuels for ships to satisfy increasingly strict emissions regulations. It can be considered a greener alternative for internal combustion engines [12, 13, and 14]. In addition, it is the transition fuel from the carbon based economy to hydrogen based economy in the transportation sector $[15,16]$. Moreover, syngas fuel can be produced from coal using Integrated Gasification Combined Cycle (IGCC) [17]. Therefore, syngas is a competitive option for power generation, compared to direct fired pulverized coal plants and natural gas fired combined cycle plants $[18,19]$.

Great majority of prime movers and auxiliary plants of ocean-going ships are diesel engines [4]. These ships are powered by low-speed, two-stroke diesel engines. The primary reasons for this dominance are their high efficiency and the use of heavy fuel oil, which is a cheap fuel. Unfortunately, it contains large quantities of sulfur and other impurities. As the international marine regulations are expected to prohibit the use of fuels with high sulfur content in the near future, gas turbine-based systems will become competitive in terms of specific fuel consumption cost [20].They can burn different types of fuels and produce lower emissions. In addition, using combustors with swirl for gas turbines helps in burning the fuel efficiently and reducing the exhaust gas emissions [21, 22,23 , and 24]. 
The aim of the paper is numerical analysis of different environmental impacts of firing syngas fuel in gas turbine combustor and predicting changes in the firing temperature and emissions, with the reference to natural gas combustion. For this purpose a numerical model for syngas fuel combustion in a can combustor has been developed. The can combustor with swirl is used to burn the syngas fuel. The obtained numerical results are compared with experimental data to validate the CFD model. The effect of syngas compositions and swirl number on both temperature distributions and pollutant emissions is discussed. Finally, $\mathrm{NO}, \mathrm{CO}, \mathrm{CO}_{2}$ and $\mathrm{So}_{\mathrm{x}}$ pollutant emissions are compared with those produced by natural gas and with IMO regulations.

\section{NUMERICAL INVESTIGATION}

The paper takes into account the effect of swirl number on the numerically obtained combustion and emissions characteristics of syngas fuel. Measurements were performed using a test rig with a swirl combustor shown in Fig. 1. Fuel and combustion air lines are used for verifying the numerical analysis. The present model was used in [25] to study the effect of secondary air configurations in a gas turbine combustor firing natural gas. The air entering the gas turbine combustor is divided into two streams, the primary air (combustion air) and the secondary air, the latter used for cooling purposes as shown in Fig. 1. The present study focuses only on the combustion air, while the secondary air is not considered since the combustor is water-cooled. Consequently, the secondary air inlets were closed during the reported runs.

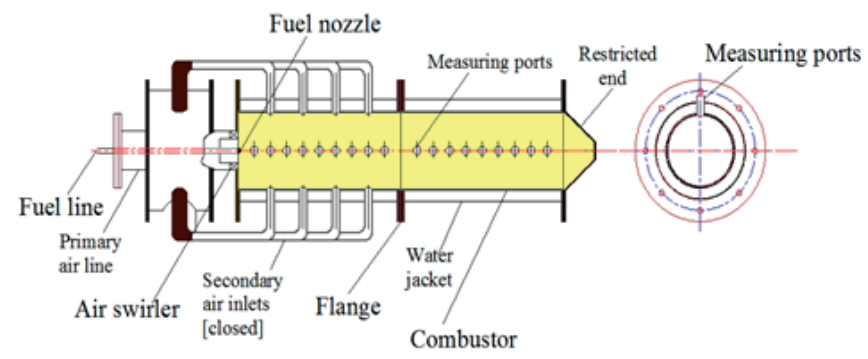

Fig. 1. Test combustor used to validate the numerical model

The primary air (combustion air) represents a small portion of the total air entering the gas turbine combustor while the big portion is used for combustor cooling. The effect of air to fuel ratio on flame size was studied by [25] using the air to fuel ratios from 30 up to 70 . It was found that the air to fuel ratio of 40 is appropriate for obtaining a suitable flame size. Therefore, the air to fuel ratio of 40 was used in the present study. The combustion air was introduced into the combustor through an air swirler mounted coaxially upstream of the combustor, while the fuel was introduced through a centrally located simple nozzle. The swirler used in this study is shown in Fig. 2.

Different air swirlers with the same basic geometry were used. Their inner swirl vane radius $\left(r_{i}\right)$ and the outer swirl vane radius $\left(\mathrm{r}_{\mathrm{o}}\right.$ ) were equal to $0.036 \mathrm{~m}$ and $0.05 \mathrm{~m}$, respectively. The swirlers had different vane angles $(\alpha)$ of $30^{\circ}, 39^{\circ}, 46^{\circ}, 52^{\circ}$ $58^{\circ}$, and $64^{\circ}$ with swirl numbers of $0.5,0.7,0.9,1.1,1.5$ and 2 , respectively. The swirl number (S) is defined as follows [26]:

$$
S=\frac{2\left(1-\left(\frac{r_{i}}{r_{0}}\right)^{3}\right) \tan \alpha}{3\left(1-\left(\frac{r_{i}}{r_{0}}\right)^{2}\right)}
$$
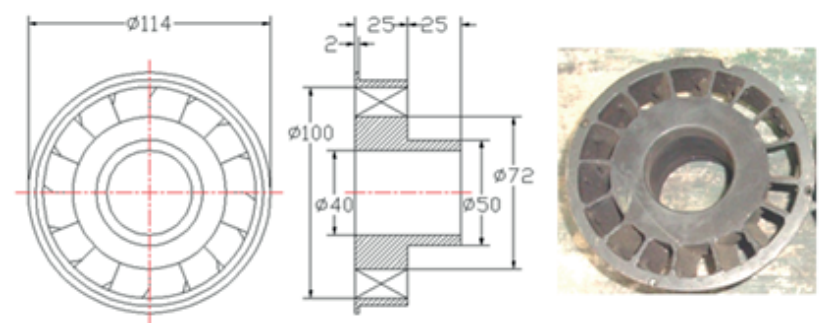

Fig.2. Air swirler used in the test combustor

\section{GEOMETRY, MESH, AND BOUNDARY CONDITIONS}

The basic geometry of the combustor used in this study is shown in Fig.3. The model geometry and the mesh were generated using the program Gambit [27]. The combustor model has a restricted end, to help in stabilizing the reverse flow zone and consequently the flame within the combustor for all swirl numbers. The dimensions of the combustor are $100 \mathrm{~cm}$ in length ( $\mathrm{z}$ direction) and $20 \mathrm{~cm}$ in diameter (x or $\mathrm{y}$ direction). The inlet combustion air is guided by the swirler vanes to give the air swirling velocity component. The fuel enters through a simple pipe of $1 \mathrm{~cm}$ in diameter, located coaxially at the center of the air swirler. The can combustor outlet shown in Fig. 3 has a conically shaped restriction end with the exit diameter of $5 \mathrm{~cm}$.

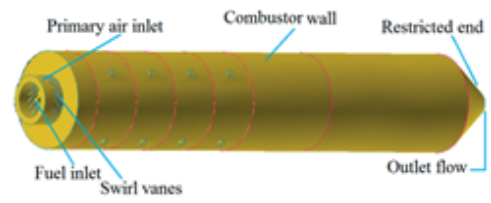

Fig.3.Geometry of gas turbine can combustor

A computational mesh was generated for the combustor and the swirler. The model and mesh shown in Figs. 3 and 4 represent a tubular combustor with an air swirler of vane angle of 45 degrees. The mesh consists of about 300,000 tetrahedral cells. The three-dimensional models available in the CFD Ansys-Fluent package were used to simulate the turbulent reacting flow. Mesh cells sizes, densities and distributions are essential for numerical solutions. Numerical accuracy can be improved by careful distribution of grid nodes, being a compromise between computational time and numerical accuracy to avoid the need for more complicated meshes. The combustor mesh is divided into a number of regions to adjust cell size distributions, taking into account their importance to numerical solutions. The mesh has high cell density for certain 
zones of interest, such as the swirler and the area upstream of the combustor, and low density in other zones of less interest, see Fig.4. The grid quality was checked by applying the quality criteria to tetrahedral mesh cells, as a result of which the maximum cell squish of 0.72 and the maximum cell skew less of 0.75 were obtained.

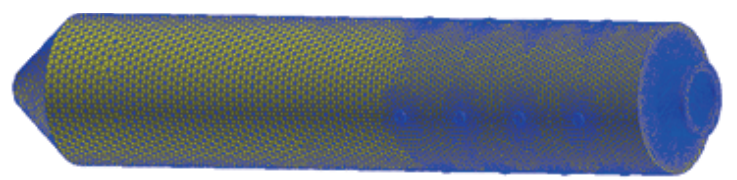

Fig.4.Computational mesh for the can combustor and air swirler

\section{CFD MODELING}

The finite volume and the first-order upwind methods were used to solve the governing equations. The mathematical equations describing the combustion process are based on the equations of conservation of mass, momentum, and energy, complemented by the equations for turbulence and combustion. The convergence criteria were set to 10-6 for the continuity, momentum, turbulent kinetic energy and its dissipation rate, energy and radiation equations, and mixture fraction. The sheer-stress transport (SST) $\mathrm{k}-\omega$ model was used to model the turbulence. Its features are given in Table 1.

The SST k- $\omega$ model has an advantage in performance over both standard k- $\varepsilon$ and $\mathrm{k}-\omega$ models. The modifications introduced to this model include the cross-diffusion term in the $\omega$ equation and a blending function to ensure that the model equations behave appropriately both in the near-wall zone and in the far-field zone [26, 28]. Then, the equations for the turbulence kinetic energy, $\mathrm{k}$, and the specific dissipation rate, $\omega$, are solved.

Tab.1. Features of turbulence models

\begin{tabular}{|l|l|l|}
\hline Model & \multicolumn{2}{|c|}{ Features } \\
\hline $\begin{array}{l}\text { Standard } \\
\text { m- } \omega\end{array}$ & $\begin{array}{l}\text { Solves for K- } \omega, \\
\omega=\text { Specific } \\
\text { dissipation rate } \\
(\varepsilon / \mathrm{k})\end{array}$ & $\begin{array}{l}\text { Recommended for low } \\
\mathrm{R}_{\mathrm{e}} \text { flow, wall bounded } \\
\text { boundary layer, and } \\
\text { for transitional flows. }\end{array}$ \\
\hline $\begin{array}{l}\text { SST K - } \\
\omega \text { model }\end{array}$ & $\begin{array}{l}\text { Variant of } \\
\text { standard K - } \omega, \\
\text { behaves like } \\
\text { K- } \omega \text { in the near } \\
\text { wall region and } \\
\text { like k }-\varepsilon \text { in the } \\
\text { free stream }\end{array}$ & $\begin{array}{l}\text { More accurate and } \\
\text { reliable for a wider } \\
\text { class of flows like } \\
\text { adverse pressure } \\
\text { gradient areas irfoils, transonic } \\
\text { shock waves, etc. }\end{array}$ \\
\hline
\end{tabular}

The non-premixed combustion with inlet diffusion model was used to model combustion in the present study. In the model, the equation for the conserved scalar is solved, and concentrations of individual component are derived from the predicted mixture fraction distribution. In the non-premixed combustion, the fuel and the oxidizer enter the reaction zone in distinct streams. The analyzed non-premixed model (NPM) has the flowing input chemistry properties: (1) the equilibrium, non-adiabatic, operating pressure equal to 101.325 Pascal, and (2) the fuel stream rich flammability limit ranging from 0.046 to 0.092 according to different fuel compositions. The boundary fuel species used in different runs are shown in Table 2. The $\mathrm{P}-1$ radiation model was used to model radiation from the flame. The model is based on the expansion of the radiation intensity into an orthogonal series of spherical harmonics. The $\mathrm{P}-1$ radiation model is the simplest case of radiation models [29, 30]. The formation of prompt nitric oxide (NO) was included in the calculations and the formation of thermal $\mathrm{NO}$ was modelled assuming that all nitrogen in the fuel is released as hydrogen cyanide $(\mathrm{HCN})$, then further reacts to form $\mathrm{NO}$ or molecular nitrogen $\left(\mathrm{N}_{2}\right.$ depending on combustion conditions. The soot distribution within the combustor is calculated using the two-step soot model with soot-radiation interaction.

Tab.2.Different fuel species for non-premixed model

\begin{tabular}{|c|c|c|c|c|c|c|}
\hline \multirow{2}{*}{ Run } & \multicolumn{7}{|c|}{ Boundary fuel species } \\
\cline { 2 - 7 } & $\mathrm{CH}_{4}$ & $\mathrm{H}_{2}$ & $\mathrm{CO}$ & $\mathrm{CO}_{2}$ & $\mathrm{~N}_{2}$ & $\mathrm{H}_{2} \mathrm{O}$ \\
\hline 1 & 0.07 & 0.26 & 0.62 & 0.028 & 0.018 & 0.004 \\
\hline 2 & 0.07 & 0.62 & 0.26 & 0.028 & 0.018 & 0.004 \\
\hline 3 & 0.07 & 0.44 & 0.44 & 0.028 & 0.018 & 0.004 \\
\hline 4 & 0.0 & 0.5 & 0.5 & 0.0 & 0.0 & 0.0 \\
\hline 5 & 0.5 & 0.25 & 0.25 & 0.0 & 0.0 & 0.0 \\
\hline 6 & 1.0 & 0.0 & 0.0 & 0.0 & 0.0 & 0.0 \\
\hline
\end{tabular}

\section{NUMERICAL SOLUTION}

After modelling the syngas combustion process in the can combustor, numerical calculations were performed and the results were displayed using the code Ansys-Fluent. Different algorithms were used to solve the governing equations. The Semi Implicit Method for Pressure Linked Equations (SIMPLE) algorithm was used for pressure/velocity coupling. This algorithm satisfies the mass conservation equation by using relations between velocity and pressure corrections. Moreover, in the areas where pressure variations between consequent mesh cells were expected to be significant, the pressure staggering scheme was used which computes the staggered pressure values at the face of each cell to capture pressure non-uniformity. The running steps of the solution procedures are as follows: (1) completing the Probability density function (PDF) look-up table calculation, (2) starting the reacting flow simulation to determine the flow files and to predict the spatial distribution of the mixture fraction, (3) continuing the reacting flow simulation until a convergence solution is achieved, and (4) determining the corresponding values of the temperature and individual chemical species mass fractions from the look-up tables. Multiple species, including radicals and intermediate species, can be included in the problem definition and their concentrations can be derived from the predicted mixture fraction using the assumption of equilibrium chemistry. The property data for the species were accessed through chemical database, and the turbulence-chemistry interaction was modeled using a beta-PDF. 


\section{GRID INDEPENDENCE STUDY}

Grid independence is an important parameter to be studied during numerical investigation. In order to obtain a gridindependent solution, the generated computational grid should be refined until the solution stops varying when increasing the number of grid cells. The effect of grid refinement on the solution was examined for the combustion air mass flow of $100 \mathrm{~g} / \mathrm{s}$. The cell numbers of the examined meshes were equal to 100,$000 ; 200,000 ; 300,000 ; 350,000$ and 400,000 cells, respectively. The axial velocity distribution is a parameter which can be successfully used in grid independence study, due to its importance in evaluating the flow field in the swirl gas turbine combustor. In particular, the locus of zero axial velocity represents the boundaries of the reversed flow zone which is responsible for flame stabilization $[31,32]$. That is why the axial velocity was used here as parameter for studying the grid independence. The axial velocities along the combustor centerline were calculated for the above assumed grid cells numbers. The obtained results show good agreement of axial velocities for grid cell numbers of 200,000 and 300,000, while the results for other cell numbers differ more, as shown in Fig. 5. Consequently, the mesh size of 250,000 cells can provide a sufficiently grid independent and accurate solution.

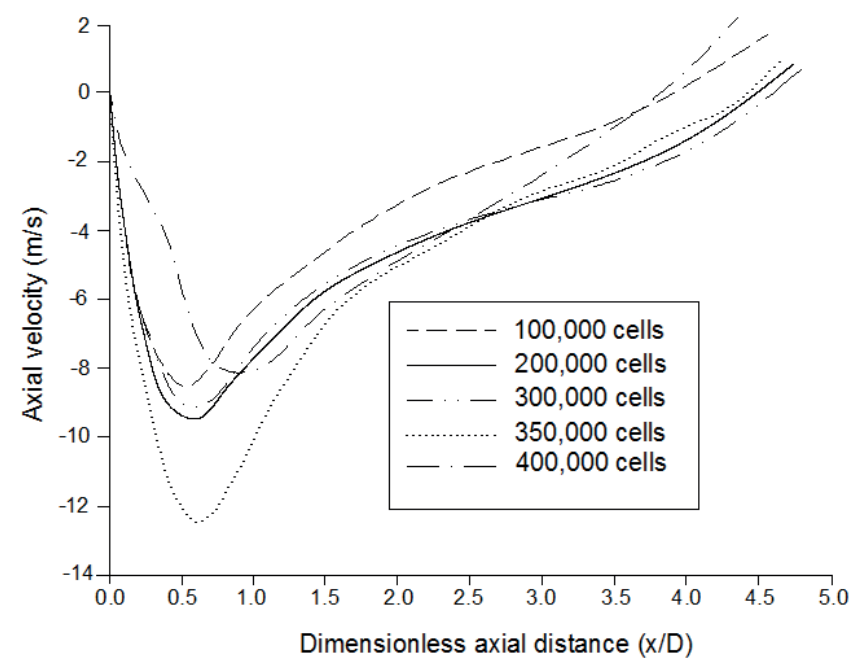

Fig.5. Grid independence study using axial velocity distribution along the combustor centerline

Boundary conditions are important for the accuracy of numerical solutions. In the present study, the inlet boundary conditions included the inlet air and fuel mass flow rates, and the outlet gas flow rate. The selected boundary conditions for the numerical solution were as follows: the inlet mass flow rates of the combustion air and the fuel were selected to give the $\mathrm{AF}$ ratio of 40 , and the inlet air and fuel temperatures were assumed equal to $300 \mathrm{~K}$. For the combustion air, the turbulence intensity was equal to $15 \%$, and the hydraulic diameter was $2.8 \mathrm{~cm}$. For the fuel, the turbulence intensity was $10 \%$, and the mean mixture fraction was 1.0. The boundary conditions for the outlet combustion flow were defined by pressure values. The relative pressure was taken with respect to the zero gage pressure, the radial equilibrium pressure distribution was assumed, the exit temperature was $1000 \mathrm{~K}$, and the exit hydraulic diameter was $5 \mathrm{~cm}$. The turbulence intensity was $10 \%$, and the hydraulic diameter was $5 \mathrm{~cm}$.

\section{MODEL VALIDATION}

The validation of the CFD model was achieved by comparing the CFD results of temperature distributions with the experimental data recorded for natural gas fuel, published by [25] where the same combustor and the corresponding mesh were used. This was performed by changing the methane fuel concentrations during runs until $100 \%$ methane was reached. Once validated, the CFD model was considered useful in analyzing different compositions of syngas fuels and consequently, the remaining results were obtained using this model. The centerline temperature distributions for $S=0.9$ and $S=1.5$, as obtained from computations and experiments, are shown in Figs. 6-a and 6-b. Comparing these results, a satisfactory and acceptable agreement is observed, with the maximum error of about $8 \%$. The computed temperatures are higher than those coming from measurements. This is due to the fact that the combustor is cooled with water, which absorbs a lot of heat, and further the heat is lost by convection and radiation. In addition, the use of a bare wire thermocouple where its junction does not sense the same temperature of the combustion gases is also a reason why the measured temperatures are relatively far from the calculated ones.

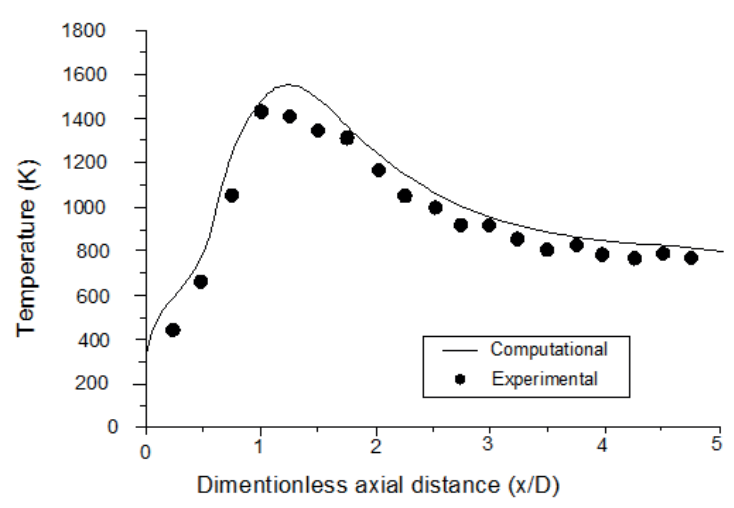

Fig.6-a. Model validation @ $(S=0.9, A F=40)$

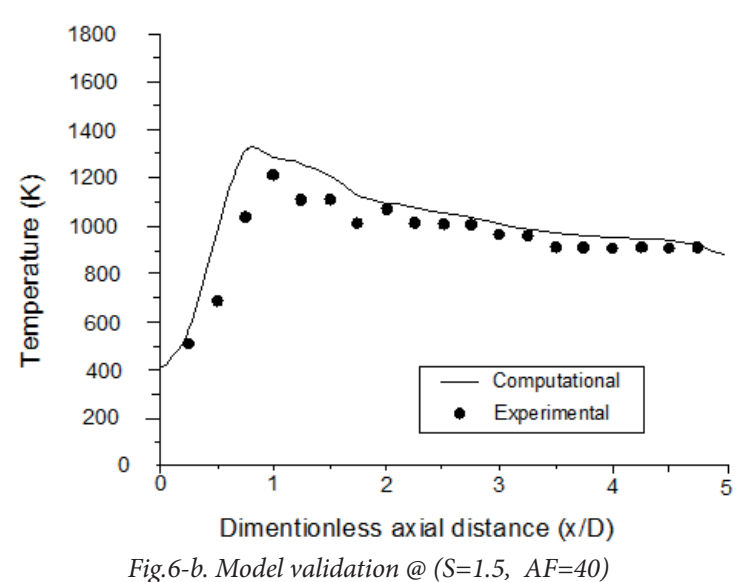

Fig.6-b. Model validation@ $(S=1.5, A F=40)$ 


\section{RESULTS AND DISCUSSION}

\section{EFFECT OF SYNGAS AND NATURAL GAS MIXTURES ON TEMPERATURE DISTRIBUTIONS}

In this section, the effect of using different mixtures of natural gas and syngas fuels on combustion characteristics is analyzed. The natural gas flame is very long at $\mathrm{AF}=20$ and 30 . Firstly, the effect of increasing $\mathrm{CH}_{4}$ percent in syngas fuel was investigated. The $\mathrm{CH}_{4}$ content was increased until it reached $100 \%$. In the reported case, $\mathrm{AF}=40$ was selected to produce a suitable flame length relative to the combustor configuration. Also, the swirl number of 0.9 was selected for the same reason, and to obtain reasonable comparisons among different cases of $\mathrm{CH} 4$ content, especially when the hydrogen content was high (longer flame).

Methane $\left(\mathrm{CH}_{4}\right)$ is an essential component in syngas and it is the main component of natural gas. Consequently, studying the effect of $\mathrm{CH}_{4}$ percent in syngas is of high importance. Two different syngas compositions were examined. The first composition was: $\mathrm{CH}_{4}=0.07, \mathrm{H}_{2}=0.62, \mathrm{~N}_{2}=0.018, \mathrm{CO}=0.26$, $\mathrm{CO}_{2}=0.028, \mathrm{H}_{2} \mathrm{O}=0.004$ [33], and the second one was: $\mathrm{CH}_{4} 0.07, \mathrm{H}_{2}=0.26, \mathrm{~N}_{2}=0.018, \mathrm{CO}=0.62, \mathrm{CO}_{2}=0.028$, $\mathrm{H}_{2} \mathrm{O}=0.004$. As can be seen, they differ by $\mathrm{H}_{2}$ and $\mathrm{CO}$ values, while other constituents remain constant. The effect of $\mathrm{CH}_{4}$ content variation in syngas fuel on temperature maps is shown in Fig. 7. As the value of $\mathrm{CH}_{4}$, increases, the flame length and the size of high temperature regions decrease. This is due to the decrease of hydrogen content in the fuel mixture. Also, as the methane percent increases, the high temperature region of the flame is shifted to the downstream end of the combustor.

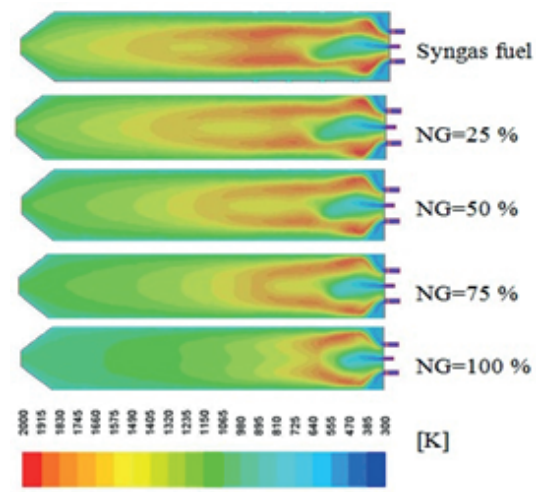

Fig.7. Temperature maps for different mixtures of syngas and natural gas fuels @ $(S=0.9, A F=40)$

Axial flame temperature distribution is an important parameter in syngas combustion. Axial temperatures for different percentages of $\mathrm{CH}_{4}$ up to $100 \%$ are shown in Fig. 8 . It can be noticed that, as the $\mathrm{CH}_{4}$ content increases, the axial temperature levels decrease in the front part of the combustor $(0 \leq \mathrm{x} / \mathrm{D} \leq 1.5)$, while in the rear part the effect of adding $\mathrm{CH}_{4}$ is reversed, i.e. the temperature levels increase with increasing the $\mathrm{CH}_{4}$ percent $(1.5 \leq \mathrm{x} / \mathrm{D} \leq 5)$.

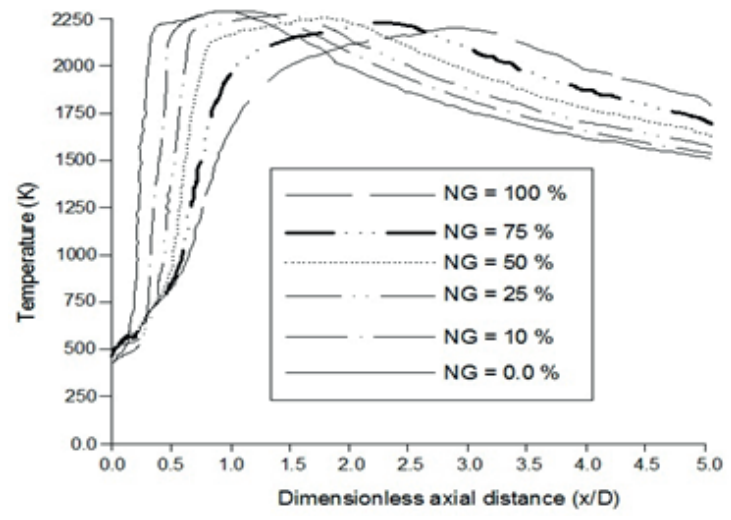

Fig.8. Effect of using different mixtures of natural gas and syngas fuels on axial temperature distributions @ $(S=0.9, A F=40)$

\section{EFFECT OF SYNGAS COMPOSITION ON TEMPERATURE DISTRIBUTIONS}

Typical syngas fuels are primarily composed of $\mathrm{H}_{2}$ and $\mathrm{CO}$, and may also contain smaller amounts of $\mathrm{CH}_{4}, \mathrm{~N}_{2}, \mathrm{CO}_{2}, \mathrm{H} 2 \mathrm{O}$, and other higher hydrocarbons. Their individual composition depends upon the fuel source and processing technology. The effect of variations in syngas compositions on the combustion and emissions in the gas turbine combustor is analyzed in this section. Different compositions of syngas fuels with different volume fractions are given in Table 3.

Tab.3. Different compositions of syngas fuels [33]

\begin{tabular}{|c|c|c|c|c|c|c|}
\hline Constituents & $\begin{array}{c}\text { Syngas } \\
\text { No } \\
(1)[\text { Schwarz } \\
\text { epumpe] }\end{array}$ & $\begin{array}{c}\text { Syngas } \\
\text { No (2) } \\
\text { [Exxon } \\
\text { Singapore] }\end{array}$ & $\begin{array}{c}\text { Syngas } \\
\text { No (3) } \\
{[\text { Tampa] }}\end{array}$ & $\begin{array}{c}\text { Syngas No } \\
(4) \\
{[\text { PSI }]}\end{array}$ & $\begin{array}{c}\text { Syngas } \\
\text { No (5) } \\
{[\text { Sarlux] }}\end{array}$ & CH $_{4}$ \\
\hline $\mathrm{H}_{2}$ & 61.9 & 44.5 & 37.2 & 24.8 & 22.7 & 0 \\
\hline $\mathrm{CO}$ & 26.2 & 35.4 & 46.6 & 39.5 & 30.6 & 0 \\
\hline $\mathrm{CH}_{4}$ & 6.9 & 0.5 & 0.1 & 1.5 & 0.2 & 100 \\
\hline $\mathrm{CO}_{2}$ & 2.8 & 17.9 & 13.3 & 9.3 & 5.6 & 0 \\
\hline $\mathrm{N}_{2}$ & 1.8 & 1.4 & 2.5 & 2.3 & 1.1 & 0 \\
\hline $\mathrm{H}_{2} \mathrm{O}$ & 0.4 & 0.3 & 0.3 & 22.6 & 39.8 & 0 \\
\hline $\mathrm{VHV}\left[\mathrm{KJ} / \mathrm{m}^{3}\right]$ & 12492 & 9477 & 9962 & 8224 & - & 33570 \\
\hline $\mathrm{LHV}[\mathrm{MJ} / \mathrm{Kg}]$ & 27.8 & 12.8 & 12.7 & 10.4 & - & 50.1 \\
\hline $\mathrm{H}_{2} / \mathrm{CO}$ & 2.36 & 1.26 & 0.8 & 0.63 & 0.74 & - \\
\hline
\end{tabular}

The syngas composition bearing the name of Schwarzepumpe syngas was selected as one of syngas types for the present analysis. The combustion of the syngas fuel in air converts all carbon and hydrogen in the syngas fuel into carbon dioxide $\left(\mathrm{CO}_{2}\right)$ and water vapor $\left(\mathrm{H}_{2} \mathrm{O}\right)$ in the products, respectively. Thus, simple chemical reactions of the syngas fuel combustion process can be expressed as follows:

$$
\begin{gathered}
\mathrm{CH}_{4}+2 \mathrm{O}_{2}+7.52 \mathrm{~N}_{2} \Rightarrow \mathrm{CO}_{2}+2 \mathrm{H}_{2} \mathrm{O}+7.52 \mathrm{~N}_{2} \\
1.5 \mathrm{CO}+0.75 \mathrm{O}_{2}+2.82 \mathrm{~N}_{2} \Rightarrow 1.5 \mathrm{CO}_{2}+2.82 \mathrm{~N}_{2}
\end{gathered}
$$

$$
\mathrm{H}_{2}+0.5 \mathrm{O}_{2}+1.88 \mathrm{~N}_{2} \Rightarrow \mathrm{H}_{2} \mathrm{O}+1.88 \mathrm{~N}_{2}
$$


The effect of hydrogen percent in syngas composition on temperature maps is shown in Fig. 9-a. The examined syngas compositions differed by hydrogen content, which amounted to $0.26,0.44,0.50$ and 0.62 . It is shown that, as hydrogen content increases in the syngas fuel, the flame length increases and the size of high temperature regions in the flame becomes larger. This is due to high burning velocity of hydrogen and its high energy content.

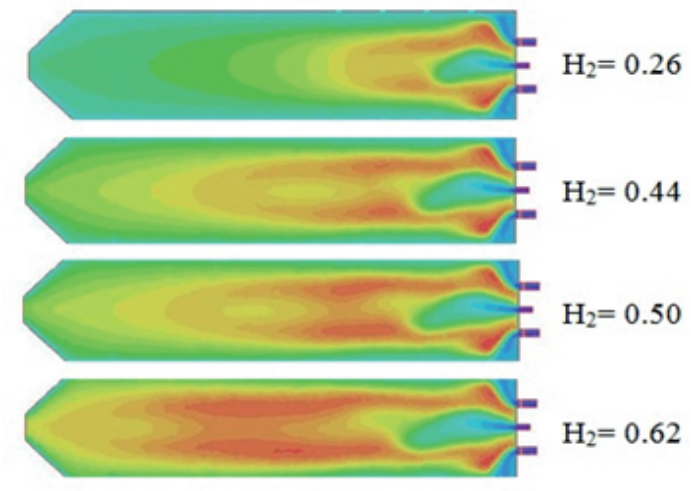

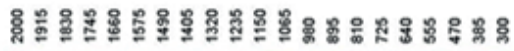

\section{$[\mathrm{K}]$}

Fig.9-a. Effect of hydrogen percent in syngas composition on temperature maps

Hydrogen content in the syngas fuel has a remarkable effect on temperature distributions. Fig.9-b shows the effect of syngas fuel composition on axial temperature distributions along the combustor centerline. It is shown that the temperature levels increase with increasing the hydrogen content at the front part of the combustor $(0 \leq x / D \leq 1.5)$. In contrast, the flame temperature levels increase with the decreasing hydrogen content in the rear part of the combustor $(1.5 \leq x / D \leq 5.5)$. This is because the flame is shorter for lower hydrogen content and the two high temperature regions around the combustor center line come closer to each other. This leads to higher temperature levels for higher hydrogen content near the fuel injector.

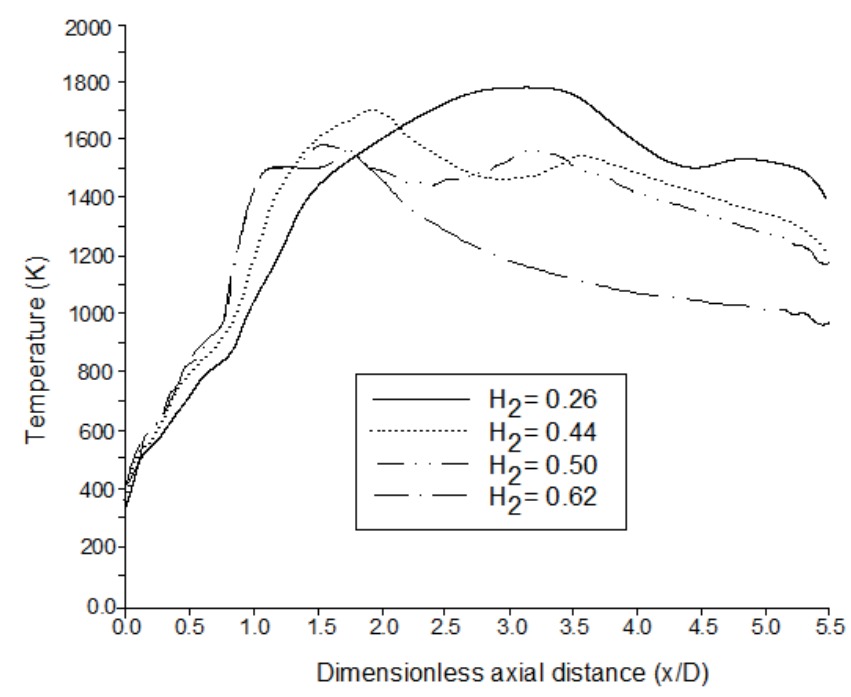

Fig.9-b. Effect of hydrogen percent in syngas fuel composition on axial temperature distributions @ $(S=0.9, A F=40)$

\section{EFFECT OF SYNGAS COMPOSITION ON POLLUTANT EMISSIONS}

Hydrogen percent in the syngas fuel has a remarkable effect on $\mathrm{CO}_{2}$ species concentrations, $\mathrm{NO}$ pollutant concentrations, and soot volume fraction along the combustor centerline. Figure10-a shows the effect of syngas fuel composition on axial distribution of $\mathrm{CO}_{2}$ species concentrations along the combustor centerline. The effect is very clear for different hydrogen contents in the syngas fuel. For $26 \% \mathrm{H}_{2}$, the volume of $\mathrm{CO}_{2}$ increases rapidly to a high mole fraction of 0.045 . Then, it decreases to a lower value of 0.02 at the combustor end. For $44 \%$ and $50 \% \mathrm{H}_{2}$, the $\mathrm{CO}_{2}$ volume also increases, but to values lower than that for $26 \% \mathrm{H}_{2}$, and then it decreased again after $\mathrm{x} / \mathrm{D} \geq 3.2$ and $\mathrm{x} / \mathrm{D} \geq 3.9$ for $\mathrm{H}_{2}=44 \%$ and $50 \%$, respectively. For $62 \% \mathrm{H}_{2}$, (Schwarzepumpe syngas fuel type) the $\mathrm{CO}_{2}$ emission is the lowest of the four examined hydrogen percentages in the syngas fuel. Comparing the results of $\mathrm{CO}_{2}$ emission with that for natural gas in [25], the use of the Schwarzepumpe syngas fuel results in lower $\mathrm{CO}_{2}$ emissions than that of natural gas fuel. The maximum values of $\mathrm{CO}_{2}$ emissions decreased from 0.088 to 0.013 mole fractions at the same operating conditions. In addition, the combustor exit values of $\mathrm{CO}_{2}$ emissions decreased from 0.048 to 0.013 mole fractions at the same operating conditions.

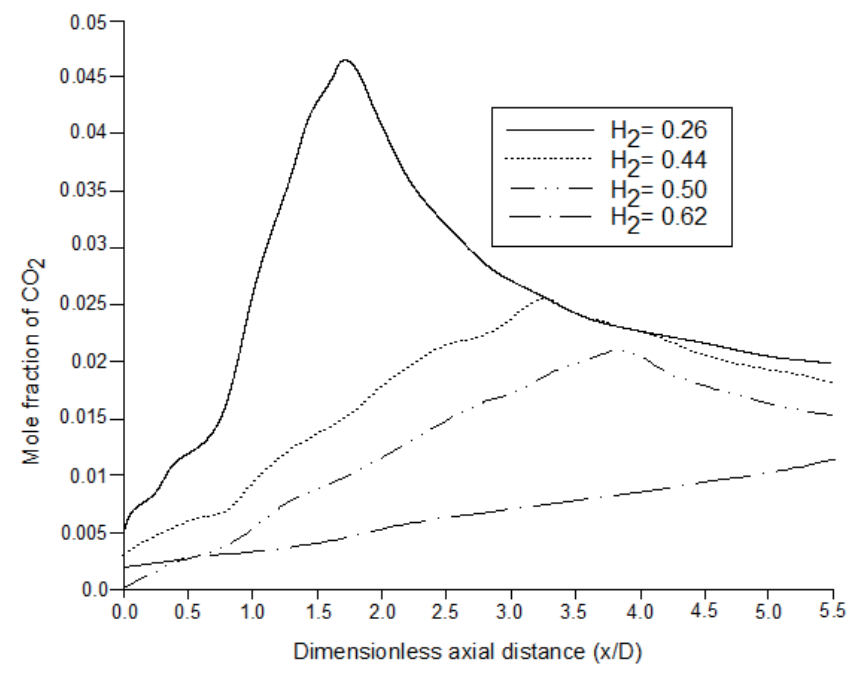

Fig.10-a. Effect of syngas fuel composition on axial distribution of $\mathrm{CO} 2$ species concentrations@ $(S=0.9, A F=40)$

Nitrogen oxide (NO) emissions from syngas combustion come primarily from two sources, which are fuel (prompt) NO formation, and thermal NO formation. Prompt NO formation is responsible for a smaller fraction of $\mathrm{NO}_{\mathrm{x}}$ emissions, unless the emission levels are very low. The fuel NO formation results from oxidation of nitrogen-bearing species, such as HCN and $\mathrm{NH}_{3}$, which evolved from the fuel during gasification. The thermal NO arises from oxidation of molecular nitrogen $\left(\mathrm{N}_{2}\right)$ in the combustion air, and is formed in appreciable quantities at elevated combustion temperatures, ranging above $1370^{\circ} \mathrm{C}$ [34]. Figure 10-b shows the effect of syngas fuel composition on axial distribution of NO pollutant concentrations along the 
combustor centerline. Both thermal and prompt mechanisms were selected for modeling NO pollutants. It is shown that NO mole fractions decrease with increasing the hydrogen content in the front part of the combustor. Then, the NO pollutant concentrations increase in the rear part of the combustor with increasing the hydrogen content. The maximum NO level remarkably increases with increasing the hydrogen content and is shifted to the rear end of the combustor. The NO values decrease sharply at the end of the combustor due to the reaction with oxygen in air to produce $\mathrm{NO}_{2}$ and $\mathrm{NO}_{3}$. Comparing the results for $\mathrm{NO}$ emissions with those published for natural gas in [25], the use of the Schwarzepumpe syngas fuel results in lower NO emission than that produced by natural gas fuel. The maximum values of $\mathrm{NO}$ emissions decreased from 0.00045 to $5 e-5$ mole fractions at the same operating conditions. The NO and $\mathrm{CO}_{2}$ results are satisfactory and agree with those reported in Ref. [35]. Consequently, the syngas fuel satisfies the new international $\mathrm{NO}_{\mathrm{x}}$ emission regulations, as the natural gas satisfies new IMO regulations on $\mathrm{NO}_{\mathrm{x}}$ emission, according to Lloyd's Register options for the compliance with new IMO regulations[36, 37].

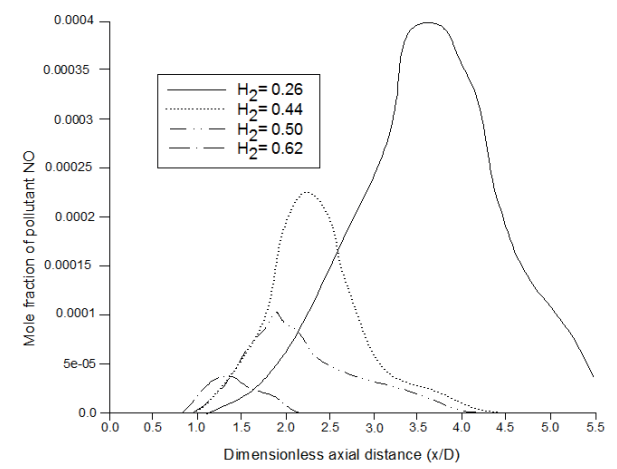

Fig.10-b. Effect of syngas fuel composition on axial distribution of NO pollutantemissions @ $(S=0.9, A F=40)$

Finally, Fig. 10-c shows the effect of syngas fuel composition on axial distribution of soot volume fraction along the combustor centerline. The maximum volume fraction of soot exists at the middle section of the combustor, for hydrogen contents of 0.44 and 0.50 . The concentration of the soot volume fraction increases for hydrogen content of 0.62 more than that for 0.26 but less than for 0.44 and 0.50 , with the maximum value more shifted towards the rear section of the combustor.

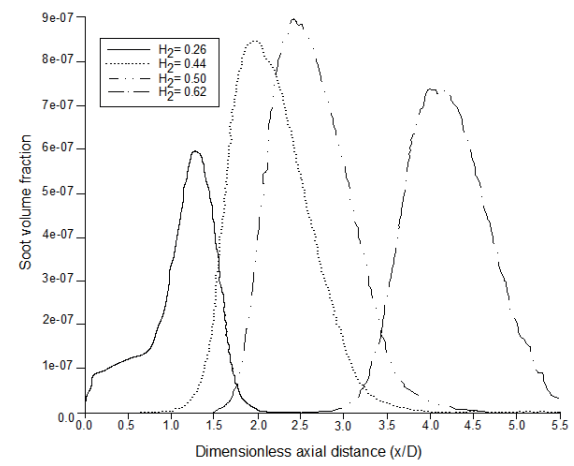

Fig.10-c. Effect of syngas fuel composition on axial distribution of soot volume fraction@ $(S=0.9, A F=40)$

\section{EFFECT OF SWIRL NUMBER ON TEMPERATURE DISTRIBUTIONS}

The zero axial velocity point divides the flow within the combustor into two zones with respect to the flow direction, which are the forward and reversed flow zones (RFZ). The RFZ is found within the recirculation zone (RZ) and has slightly smaller volume than RZ. So, the two zones can be considered the same. For high swirl numbers, the adverse axial pressure gradient is sufficiently high to result in reverse flow along the combustor axis and setting up an internal RZ. This RZ plays an essential role in flame stability. It constitutes a mixed zone of combustion products and acts as a source of heat. It chemically actives species near the swirler exit.

The air swirl number was changed by using six swirlers with the same dimensions but different vane angle inclinations, ranging from $30^{\circ}$ up to $64^{\circ}$. For swirl numbers above 0.5 , the RFZ took the shape of a closed loop and ended inside the combustor. This helps in shortening the flame. The filled contours of flame temperatures or temperature maps indicate the flame shape and size. Figures 11-a and 11-b show the effect of swirl number on syngas and natural gas temperature maps at different swirl numbers, from 0.5 to 2.0. It is shown that, as the swirl number increases, the flame size decreases and the high temperature regions become attached to the upstream direction. Consequently, the flame length is decreased. The temperature maps are nearly the same for moderate swirl numbers $S=0.7$ and $S=0.9$. But for $S>1$ (strong swirl), the swirl number has more effect on the flame size.

As the swirl number increases, the high temperature regions are shifted upstream, since the RFZ moves relative to the swirler exit. Also, for lower swirl numbers, a higher flame temperature is obtained since the residence time for the mixture is reduced. Thus, the fuel is efficiently burned and the emissions of pollutants are reduced. This is due to good mixing of the fuel and air. The combustion process is enhanced and this leads to lower emissions.

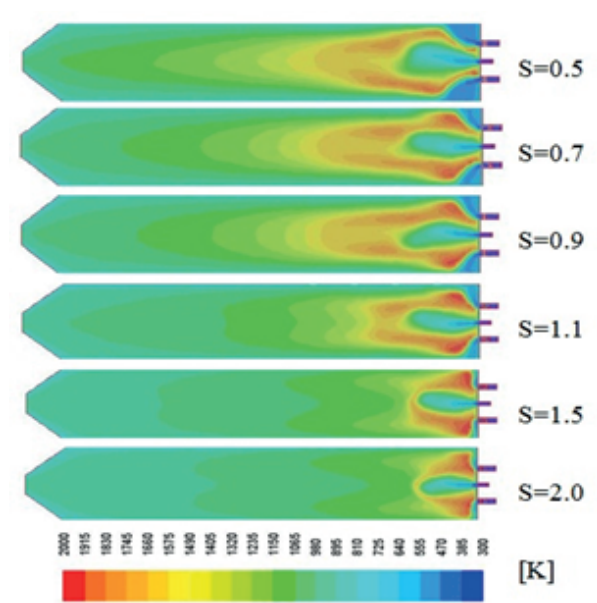

Fig.11-a. Effect of swirl number on temperature maps of syngas fuel flames @ $(A F=40)$ 


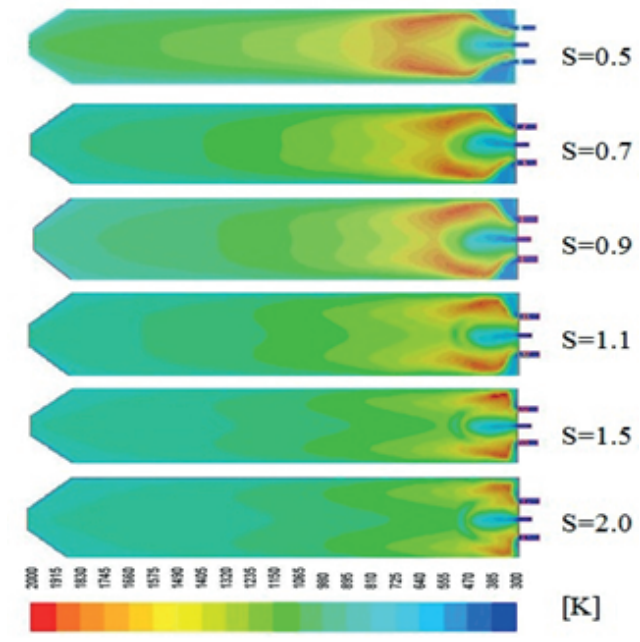

Fig.11-b. Effect of swirl number on temperature maps of natural gas flames @ $(A F=40)$

Swirl number has an effect on the temperature distribution, since increasing the swirl number leads to the decrease of the flame size and, consequently, to the reduction of the flame temperature inside the combustor, partially at the combustor end. This is a benefit when selecting the turbine blade material. Fig. 12 shows the effect of swirl number on axial temperature distributions along the combustor centerline. It is shown that, as the swirl number increases, the temperature level increases in the front part of the combustor and decreases in the rear part. The temperature increase in the front combustor part is due to good mixing between fuel and air, as a result of high turbulence intensity caused by higher swirling effect. Far from the swirler exit, the swirl effect and the turbulence decrease, and this leads to the decrease of the temperature levels.

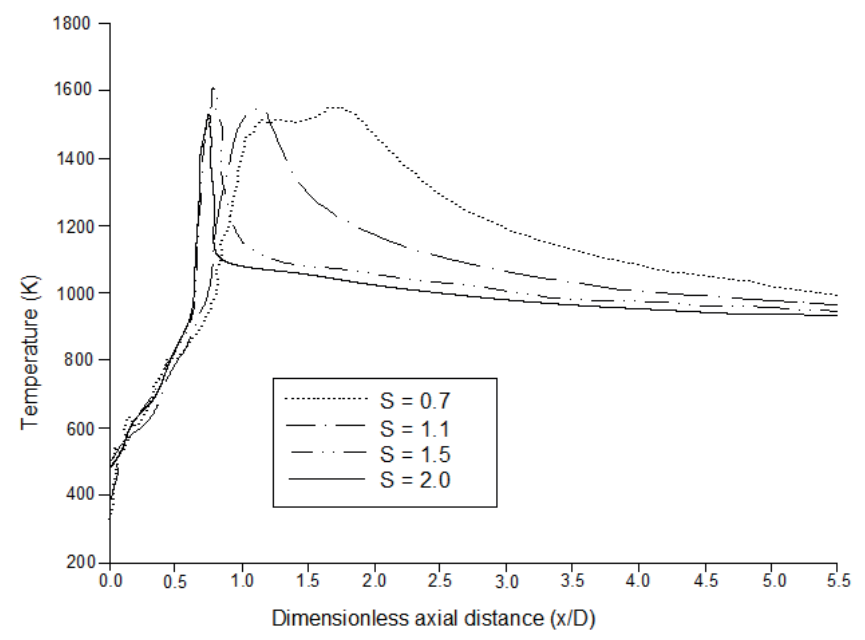

Fig.12. Effect of swirl number on axial temperature distributions @ $(A F=40)$

\section{EFFECT OF SWIRL NUMBER ON POLLUTANT EMISSIONS}

Air swirl number has an obvious effect on the flow field and combustion inside the gas turbine combustor. As the swirl number increases, the reverse flow zone also increases and flame stabilization is improved. Combustion characteristics are enhanced by improving flame stabilization, as shown in details in Figs. 13-a and 13-b. Figure 13-a shows the effect of swirl number on unburned fuel Carbon monoxide species. $\mathrm{CO}$ in syngas combustion products comes from two primary sources: (1) unburned syngas $\mathrm{CO}$, resulting from inefficient fuel/air mixing which creates regions with equivalence ratios outside the ignition range, and (2) incomplete combustion of hydrocarbon species in the syngas. CO emissions from gas turbine-based IGCC systems are lower than those produced by conventional combustion-based systems [38]. The hydrogen content in synthesis gaseous fuels extends the operational limit and facilitates the oxidation of other organic fuel fractions by providing elevated combustion temperatures. For turbine and boiler applications, $\mathrm{CO}$ emissions from syngas combustion are lower than those observed in diesel or spark ignition engines [34].Comparing the results for $\mathrm{CO}$ emissions with those for natural gas in [25], the use of the Schwarzepumpe syngas fuel results in higher $\mathrm{CO}$ emission than that of natural gas fuel. The maximum values of $\mathrm{CO}$ emissions increased from 0.028 to 0.14 mole fractions at the same operating conditions. However, the maximum CO value for syngas decreases at the end of the combustor, but is still slightly higher than that of natural gas. This result agrees with those reported in Ref. [35].

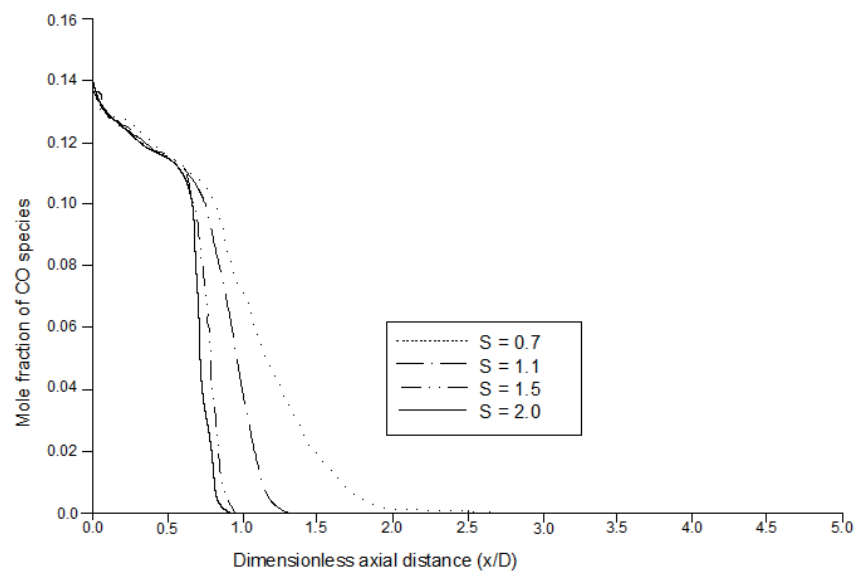

Fig.13-a. Effect of swirl number on axial CO species concentration @ (AF=40)

Figure 13-b shows the effect of swirl number on unburned fuel species $\mathrm{H} 2$. The $\mathrm{H} 2$ concentrations decrease along the combustor length and approach zero at about $\mathrm{x} / \mathrm{D} \leq 2$, due to burning out. Also, the $\mathrm{H} 2$ concentrations decrease along the combustor centerline with the increase of the swirl number and approach zero for all swirl number (S), in the combustor part between $2.0 \leq \mathrm{x} / \mathrm{D} \leq 5$. In addition, as the swirl number increases, the $\mathrm{N} 2$ concentrations decrease along the combustor centerline in the combustor section $(\mathrm{x} / \mathrm{D} \leq 1.5)$, remaining nearly constant in subsequent sections, as shown in Fig. 13-c. Figs. 13-d and 13-e show that as the swirl number increases, the concentrations of $\mathrm{HCN}$ and $\mathrm{CO} 2$ decrease in the rear section of the combustor, at $x / D \geq 1.5$. In the other part of the combustor this trend is inversed, due to the turbulence effect produced by the swirling flow which improves air/fuel mixing. As a consequence, the exhaust gas emissions decrease in the end part of the combustor size. 


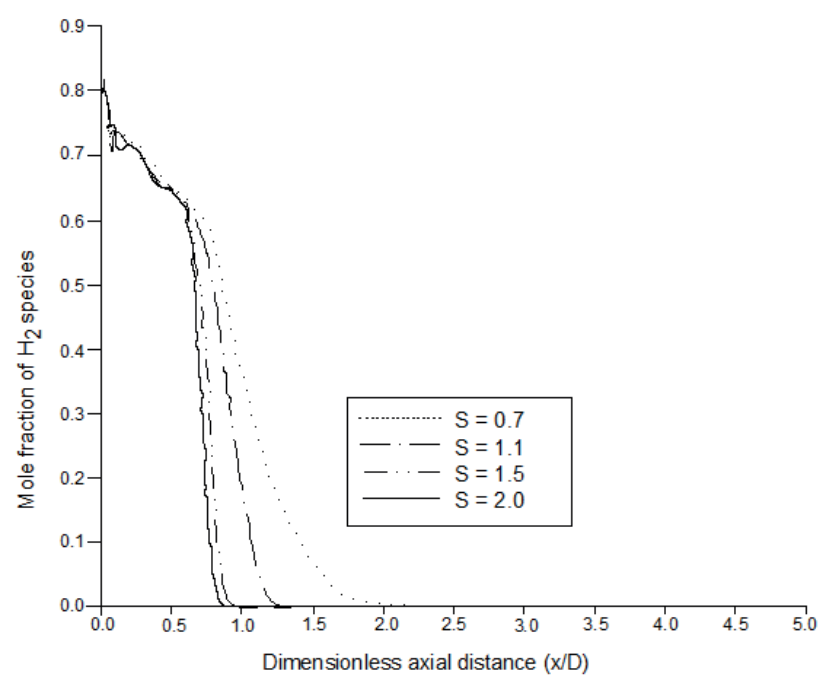

Fig.13-b. Effect of swirl number on axial $\mathrm{H}_{2}$ species concentration@ $(A F=40)$

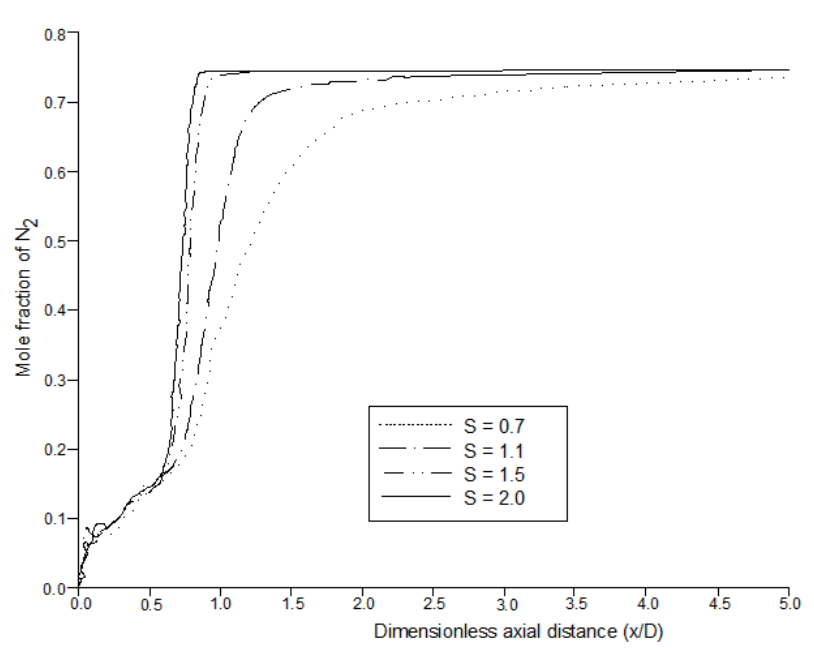

Fig.13-c. Effect of swirl number on axial $N_{2}$ species concentration @ $(A F=40)$

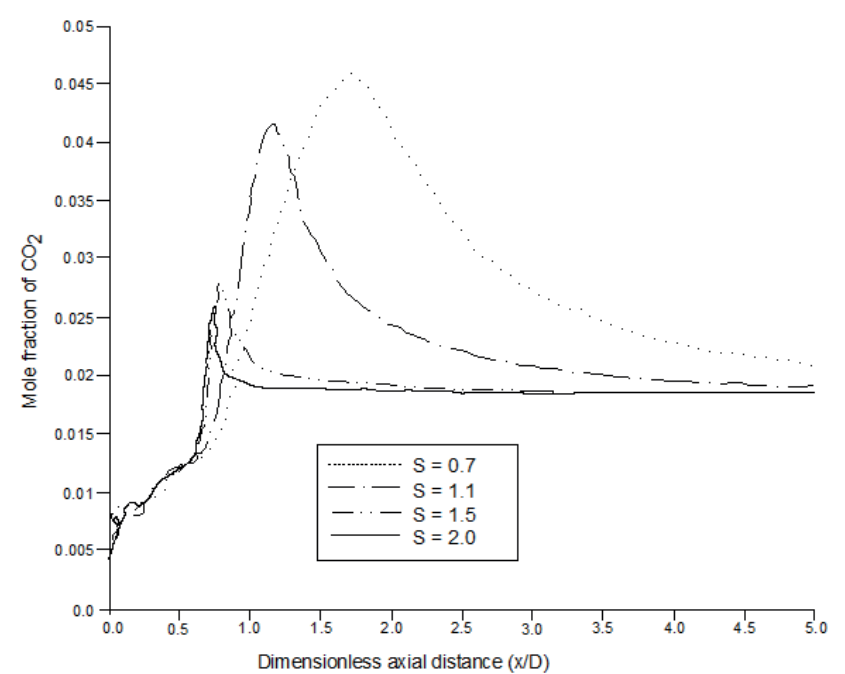

Fig.13-d. Effect of swirl number on axial $\mathrm{CO}_{2}$ species concentration @ $(A F=40)$

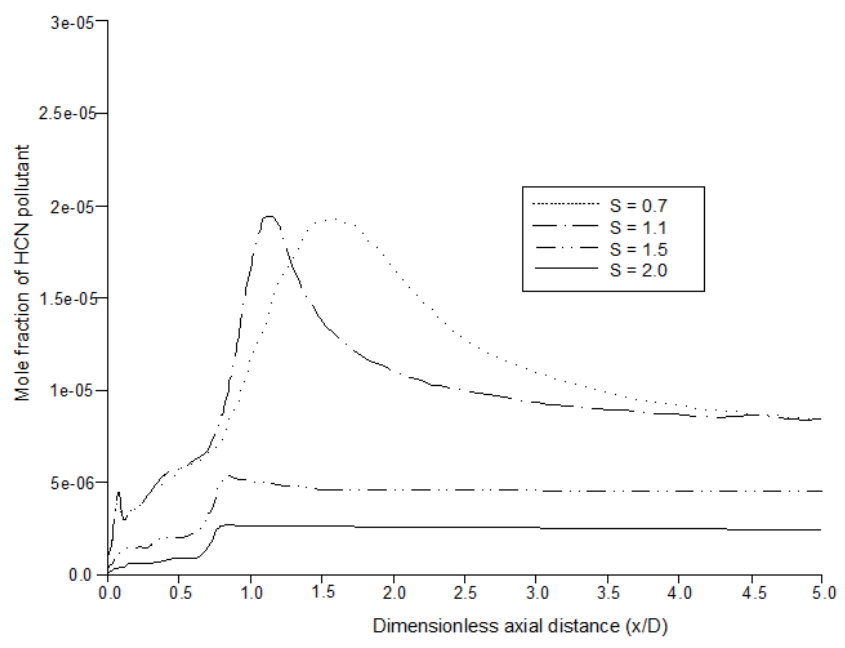

Fig.13-e. Effect of swirl number on axial HCN pollutant concentration@ $(A F=40)$

Finally, a sulfur component in the syngas fuel is hydrogen sulfide, the concentrations of which can exceed $2 \%$ for sulfurrich fuels. Lower concentrations of other reduced sulfur compounds, such as carbonyl sulfide, mercaptans, dimethyl sulfide, dimethyl disulfide, and carbon disulfide, may also be observed. Prior to combustion in the gas turbine, nearly all sulfur compounds are to be removed from the synthesis gas [39]. The syngas fuel used in the present paper contains no sulfur, and there are no emissions of sulfur oxides from the can combustor. This satisfies the international IMO $\mathrm{SO}_{\mathrm{x}}$ emission regulations.

\section{CONCLUSIONS}

Numerical modeling of syngas fuel combustion in a can combustor with swirl is presented as a solution proposed to satisfy the requirements of international marine regulations. Four examined syngas fuel compositions differed by $\mathrm{H}_{2} / \mathrm{CO}$ ratios, ranging from 0.63 up to 2.63 . Also, mixtures with different natural gas-syngas ratios were investigated. The SST k- $\omega$ model was used for turbulence modeling. The nonpremixed combustion model was used to model combustion, and P-1 for modeling radiation. The effect of syngas fuel compositions on the flame size, axial temperature, as well as on emissions of carbon dioxide $\left(\mathrm{CO}_{2}\right)$ and nitrogen oxides (NO) was examined. Based on the reported study the following conclusions have been formulated:

1. Comparing the measured and calculated axial temperatures of natural gas combustion for swirl numbers of 0.9 and AF ratio of 40, provided satisfactory agreement.

2. At lower swirl numbers, the temperature levels are high. Also, it has been noticed that in those cases the high temperature regions have large sizes for both natural gas and syngas fuels.

3. With increasing the swirl number, the temperature levels and the high temperature region decrease. They also shift towards the front of the combustor, thus leading to the decrease of the flame length. 
4. Increasing the swirl number leads to the decrease in axial temperature levels, and $\mathrm{CO}, \mathrm{H}_{2}, \mathrm{HCN}$ and $\mathrm{CO}_{2}$ concentrations. At the same time the $\mathrm{N}_{2}$ concentrations increase along the combustor centerline. The syngas composition has a remarkable effect on flame shape and size as indicated in the temperature maps. The flame length and the size of high temperature regions increase with the increased hydrogen content in the syngas fuel.

5. Syngas combustion temperature levels depend on the combustible constituents (hydrogen, carbon monoxide, and methane), and on their heating values and the presence of non-combustibles (inert) constituents in the syngas fuel.

6. Axial temperatures of syngas fuel increase with the increase of hydrogen content, especially at the end of the combustor.

7. The concentrations of pollutant species depend on syngas constituents (hydrogen, carbon monoxide, and methane). The volume of $\mathrm{CO}_{2}$ decreases with the increase of hydrogen content, while NO emissions increase as the hydrogen content increases.

8. Temperature levels for syngas flames are lower than those of natural gas. Increasing the methane content leads to the increase of axial temperatures, in particular near the combustor end.

9. Syngas fuel has lower emissions of $\mathrm{NO}$ and $\mathrm{CO}_{2}$ than those from natural gas fuel at the same operating conditions. It has higher peak flame temperature and CO emissions, as compared to natural gas fuel at the same operating conditions. Also, the used syngas fuel has no sulfur oxides emissions.

10. Finally, using syngas fuel in the can gas turbine combustor with swirl can meet the required new IMO emission regulations.

\section{REFERENCES}

1. VianaM., et al., Impact of maritime transport emissions on coastal air quality in Europe. Atmospheric Environment 90,pp. 96-105, 2014.

2. Wang C., Corbett J.J., Firestone J., Improving spatial representation of global ship emissions inventories. Environmental Science and Technology 42, pp. 193199,2008 .

3. EEA.: Transport indicators tracking progress towards environmental targets in Europe. The Contribution of transport to air quality.EEA, Copenhagen, 2012.

4. Eyringer V., Köhler H. W., Lauer A., Lemper B., Emissions from international shipping: 2. Impact of future technologies on scenarios until 2050. J. Geophys 110, D17306,2005.

5. Corbett J.J., Winebrake J.J., Green E.H., KasibhatlaP., Eyring V., LauerA., Mortality from ship emissions: a global assessment. Environmental Science and Technology 41, pp. 8512-85182007.
6. Endresen Ø., Sørgård E., Sundet J.K., Dalsøren S.B., Isaksen I.S., Berglen T.F., Gravir G., Emission from international sea transportation and environmental impact. Journal of Geophysical Research: Atmospheres, pp. 108, 2003.

7. Ülpre H., Eames I., Environmental policy constraints for acidic exhaust gas scrubber discharges from ships. Marine Pollution Bulletin 88,pp. 292-301, 2014.

8. IMO.: Second IMO GHG study. London, UK, 2009.

9. RavenJ., Caldeira K., Elderfield H., Hoegh-Guldberg O., Liss P., Riebesell U., Shepherd J., Turley C., Watson A.: Ocean acidification due to increasing atmospheric carbon dioxide. The Royal Society: The Science Policy Section, 2005.

10. Blatcher D., Eames I., Compliance of royal navy ships with nitrogen oxide emissions legislation. Mar. Pollut. Bull 74, pp. 10-18, 2013.

11. CalleyaJ., PawlingR., GreigA., Ship impact model for technical assessment and selection of Carbon Dioxide Reducing Technologies (CRTs). Ocean Engineering 97, pp. 82-89,2015.

12. AzimovU., TomitaE., KawaharaN., and DolS. S., Combustion characteristics of syngas and natural gas in micro-pilot ignited dual-fuel engine. World Academy of Science, Engineering and Technology 6(12), pp. 1595$1602,2012$.

13. Weaver C.: Natural gas vehicles - a review of the state of the art. SAE technical paper 892133, doi:10.4271/892133, 1989.

14. Nichols R.J., The challenges of change in the auto industry: Why alternative fuels? J.Eng.Gas Turb Power 116,pp. $727-$ 32, 1994.

15. Lieuwen T., Yang V., Yetter R.: Synthesis gas combustion: Fundamentals and applications. Taylor \& Francis Group, 2010.

16. MuradovN. Z., and VezirogluT. N., Green path from fossil-based to hydrogen economy: An overview of carbon neutral technologies. Int. J. Hydrogen Energy 33,pp. 6804-6839, 2008.

17. RiboldiL.,Bolland O., Pressure swing adsorption for coproduction of power and ultrapure $\mathrm{H} 2$ in an IGCC plant with $\mathrm{CO} 2$ capture. International Journal of Hydrogen Energy 41(25), pp. 10646-10660, 2016.

18. Funke H. H.-W., et al., Experimental and numerical study of the micro mix combustion principle applied for hydrogen and hydrogen- rich syngas as fuel with increased energy density for industrial gas turbine. Applications Energy Procedia 61, pp. 1736 - 1739, 2014. 
19. BouvetN., et al., Characterization of syngas laminar flames using the Bunsen burner configuration. International Journal of Hydrogen Energy 36, pp. 992-1005, 2011.

20. Domachowski Z., Dzida M., An analysis of characteristics of ship gas turbine propulsion system (in the light of the requirements for ship operation in the Baltic Sea). Pol. Marit, [special issue], pp. 73-78, 2004.

21. Khalil A. E. E., Gupta A. K., Swirling flow-field for colorless distributed combustion. Applied Energy 113, pp. 208-218,2014.

22. Lilley D.G., Modeling of combustor swirl flows. Acta Astronautica 1(9-10), pp. 1129-1147,1974.

23. Syred N., Beér J.M., Combustion in swirling flows: A review. Combustion and Flame 23(2), pp.143-201, 1974.

24. Osvaldo V-Z. M., Syred N., Agustín V-M., Daniel D. R-U., Flashback avoidance in swirling flow burners. Ingeniería, Investigacióny Tecnología 15(4), pp. 603-614,2014.

25. Zaid A., FaragA.: Effect of secondary air configuration in gas turbine combustor firing natural gas. Proceedings of the ASME 2014 International Mechanical Engineering Congress \& Exposition IMECE2014, Montreal, Quebec, Canada, November 14-20, 2014.

26. Beer J.M., and Chigier, N.A.: Combustion Aerodynamics, Applied Science Publishers, London, England, 1972.

27. GAMBIT team: GAMBIT program user guide, September 2006.

28. Knopp T., Eisfeld B., Calvo J. B., A new extension for $\mathrm{k}$ $-\Omega$ เ turbulence models to account for wall roughness. International Journal of Heat and Fluid Flow 30, pp. 5465, 2009.

29. Cheng P., Two-dimensional radiating gas flow by a moment method. AIAA Journal 2, pp. 1662-1664, 1964.

30. Siegel R., Howell J. R.: Thermal radiation heat transfer. Hemisphere, Washington, DC, USA, 1992.

31. Ahmed A. S., Velocity measurements and turbulence statistics of a confined isothermal swirling flow. Experimental Thermal and Fluid Science 17, pp. 256 $264,1998$.

32. AndreiniA., et al., CFD analysis of NOx emissions of a natural gas lean premixed burner for heavy duty gas turbine. Energy Procedia 81, pp. 967 - 976, 2015.

33. Ghenai C., Combustion of syngas fuel in gas turbine can combustor. Hindawi publishing corporation. advances in Mechanical Engineering, doi:10.1155/2010/342357, pp. $1-13,2010$.
34. Whitty K. J., Zhang H. R., and Eddings E. G., Emissions from syngas combustion. Combust. Sci. and Tech. 180, pp. 1117-1136, 2008.

35. Chacartegui R., et al., Analysis of main gaseous emissions of heavy duty gas turbines burning several syngas fuels. Fuel Processing Technology 92, pp. 213-220, 2011.

36. WelayaY.M., Mosleh M., Ammar N.R., Thermodynamic Analysis of Combined Solid Fuel Cell with a Steam Turbine Power Plant for Marine Applications. Brodgradnja/ Shipbuilding 65(1), pp. 97-115, 2014.

37. Welaya Y.M., Mosleh M., Ammar N.R., Thermodynamic analysis of a combined gas turbine power plant with a solid oxide fuel cell for marine applications. Int. J. Naval Archit. Ocean Eng. 5 , pp. 404-413, 2013.

38. Mustafi N.N., Miraglia Y.C., Raine R.R., Bansal P.K., and Elder S.T., Sparkignition engine performance with 'Powergas' fuel (mixture of $\mathrm{CO}=\mathrm{H} 2$ ): A comparison with gasoline and natural gas. Fuel 85(12-13), pp. 1605-1612, 2006.

39. Ratafia-Brown, J.A., Manfredo L.M., Hoffman J.W., Ramezan M., and Steigel G.J.: An environmental assessment of IGCC power systems. Presented at the Nineteenth Annual Pittsburgh Coal Conference, Pittsburgh, PA, 23-27 September, 2002.

\section{CONTACT WITH THE AUTHOR}

Nader Ragab Ammar

Naval Arch. \& Marine Eng. Dep.

Faculty of Engineering

Alexandria University

EGYPT 